\title{
Report about the present condition of Billroth's stomach specimens
}

\author{
Hiroshi Sato ${ }^{1} \cdot$ Hirokazu Noshiro ${ }^{2}$ \\ Received: 18 June 2019 / Accepted: 30 June 2019 / Published online: 9 July 2019 \\ (c) The International Gastric Cancer Association and The Japanese Gastric Cancer Association 2019
}

On January 29th 1881, Theodor Billroth of Vienna University, carried out a successful pylorectomy (distal gastrectomy) on the 43 year old gastric cancer female patient, Therese Heller [1]. The reconstruction was done by gastroduodenal anastomosis along the minor curvature. She died of residual disease 4 months after the operation. Autopsy, which was carried out to investigate the result of their brand new operation, confirmed that the gastro-duodenal anastomosis had been successfully accomplished. From the view-point of surgical history, Billroth's first pylorectomy should be considered a surgical landmark. Following the operation, specimens were preserved and exhibited in Medical Historical Museum of Vienna University, known as Josephinum, for the purpose of safeguarding Billroth's memorable achievement $[2,3]$.

We had an opportunity to visit Josephinum and to look at the aforementioned specimens, thanks to the courtesy and good grace of Professor Yuko Kitagawa from the Department of Surgery at Keio University and ISDE 2018s Congress President. On September 19th 2018, guided by Dr.
Ruth Koplizek, a curator at Josephinum, we were able to inspect Billroth's specimens. However, we were concerned at the present condition of the specimens which had been preserved with formalin for more than 130 years. Ms. Julia Wechselberger, a restorer of those specimens, was also worried about their current state and confessed that it is difficult to further maintain their condition from now on due to the tissue condition (Fig. 1).

It is not an exaggeration to say that the development of gastric cancer surgery in the world owes much to Billroth's endeavor to introduce surgical methods for treatment of gastric cancers using experimentation on animals and cadavers, and to his first successful pylorectomy in 1881 . I hereby formally notify the esteemed members of the Japanese Gastric Cancer Association of the present and precarious condition of Billroth's commemorative specimens.
Hiroshi Sato

billroth0228@hotmail.co.jp

1 Department of Surgery, Kunisaki City Hospital, Kunisaki, Oita 873-02981, Japan

2 Department of Surgery, Faculty of Medicine, Saga University, 5-1-1 Nabeshima, Saga 849-8501, Japan 


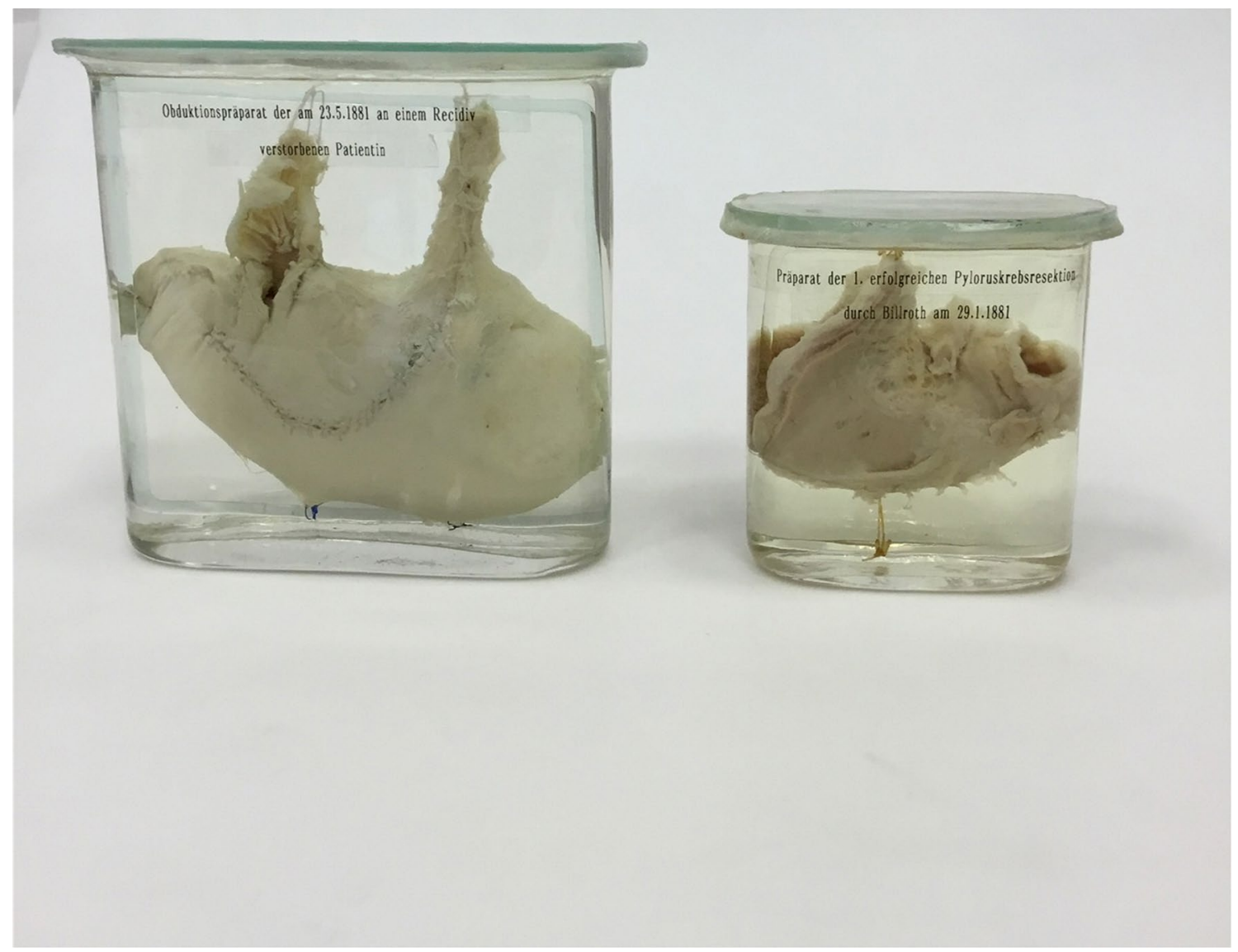

Fig. 1 The photos of Billroth's stomach specimens. Left: autopsy specimen. Right: pylorectomy specimen

\section{Compliance with ethical standards}

Conflict of interest The authors declare no conflicts of interest in association with the present manuscript.

Informed consent This article does not contain any studies with human or animal subjects performed by any of the authors.
2. Lesky E. Die Wiener Medicinische Schule im 19. Jahrhundert. Verlag Hermann Bohlaus Nachf., Graz-koln, 1965.

3. Regal W, Naut M. Vienna A doctor's guide 15 walking tours through Vienna's medical history. Wien: Springer; 2007.

Publisher's Note Springer Nature remains neutral with regard to jurisdictional claims in published maps and institutional affiliations.

\section{References}

1. Woelfler A. Ueber die von professor billroth ausgefuhrten resectionen des carccinomatosen pylorus Wilhelm braumuller (k.k.hofund universitatsbuchhandler), Wien; 1881. 